\title{
青果物の品質保持ならびに品質向上に関する 実用的技術の開発
}

\author{
Development of Practical Techniques on Keeping Quality and Quality \\ Improvement of Vegetables and Fruits
}

\author{
永井耕介* \\ NAGAI Kousuke* \\ * Hyogo Prefectural Agricultural Institute \\ 1533, Behutyo, Kasai-shi, Hyogo 679-0198
}

最近の青果物に対する消費者ニーズは健康志向の高 まりに伴い, 栄養価, 機能性, 安全性等に関心が向け られ，品質面以外にも栽培方法について注目されるよ うになってきた。品質面では高鮮度, 良食味への要求 が一層顕著になっている ${ }^{1), 2)}$ 。また消費動向は婦人の 社会進出や核家族化等を反映し, 利便性, 多品目少量 消費の傾向にあり, 小家族の約 5 割が現在の販売単位 が大きすぎる(多すぎる) と感じている2)。このよう な消費者志向の変化に対応して, 流通・販売面ではブ ランド化（生産者の顔が見える，フードプラン，安心 安全など), 多品目化, 個包装化が進み, 店頭には数 多くの野菜, 果実が陳列され, その商品形態はカット 野菜などにみられるように大半がプリパッケージされ た形態に変化してきている。一方, 青果物の生産地は 従来の重要な供給源であった都市近郊産地から遠隔地 帯へと移行しており, 今後も産地の遠隔化と広域化は 一段と進展すると予想される。そのような状況下で, 青果物における品質保持の技術開発の重要性は一層増 すものと考えられる。

公設の試験場で13年間, この種の研究に従事してき た筆者はこれまで生産や流通の現場で多くの品質低下 の問題に直面してきた。問題解決のために取り組んで きた研究の中からいくつかを以下に紹介する。

\section{1．完熟トマトの高品質化と品質保持技術}

「樹で熟した完熟トマト」は, 栽培面から土壤養分,
植物体の栄養状態に基づいた肥培管理，品質面から収 穫時のトマトについて甘味・酸味の検査を行い, 一定 の基準を満たしたトマトを「美味しいトマト」として 流通させたもので, 昭和 57 年に兵庫県で誕生した。こ の「美味しいトマトづくり事業」は県の試験場が農業 改良普及七ン夕一, 生産者, 農協, 流通業者, 小売店 等の生産，流通，販売に至る一貫した協力を得て実施 したものであった。「樹で熟させた美味しい完熟トマ ト」は消費者にも大いに喜ばれ，たちまち全国に広ま っていった。トマトの味がよくなり消費拡大にも大き く貢献したプロジェクト事業であった。この当時, 筆 者は農業試験場園芸部でトマトの栽培部門を担当して おり, 品種選定や栽培技術でこの事業に哚くかかわっ ていた。まさに消費者ニーズに沿ったトマトづくりで あると確信していた。その数年後, 流通利用部門に仕 事が変わり, 市場調查して驚いたのは, 市場では完熟 トマトから幾分緑色のトマトに逆戻りしていたことで ある。その理由は出荷流通形態や方法が以前の「一部 色着いたトマト」のものと同じであったために, 完熟 トマトの流通途上での過熟や損傷などによる品質劣化 が生じていた。このときほど, 消費者ニーズと市場二 一ズの違いを思い知らされたことはなかった。流通部 門での筆者の最初の仕事が完熟トマトを生産者から消 費者まで品質を低下させることなく流通できる技術を 確立することであった。

当時のトマト流通は, 集荷時に予冷されているもの

*兵庫県立中央農業技術センター農業試験場環境部（テ 679-0198 兵庫県加西市別府町1533） 
もあったが，その後の保冷はほとんどされていないた め，流通中に完熟卜マトが過熟になっていた。市場で トマトに水滴があれば予泠品と認められていたことか らもそのことがわかる。

予冷効果は，トマトの中心温度を測定した結果，夏 季高温時に予冷で $5{ }^{\circ} \mathrm{C} ま て ゙$ 品温を低下させても約 24 時 間後には, 箱詰めトマトの品温は室温とほほ同じ温度 に上昇し，予冷のみでは熟度の進みを抑制することが 困難であった。しかしながら, 収穫後, 予冷で品温を $5{ }^{\circ} \mathrm{C}$ に下げ, その後 $5{ }^{\circ} \mathrm{C} に$ 保冷することで, 夏季高温 時でも 1 週間程度, 糖, 酸, ビタミンC等の内容成分 や食味が優れた状態に保てることが明らかになった (Fig. 1) $)^{3)}$

もう一つの品質低下は通称「あたり」といわれる物 理的損傷である。落下や果実同士の接触で生じるが, 流通段階の振動が物理的損傷に大きく影響するものと 考えられた。そこで, IMV製振動試験機（Fig. 2）を 用いて，完熟トマトの輸送性やパッケージ方法などを 検討した。

$1,000 \mathrm{~km}$ のトラック輸送試験に使われるJIS規格の振 動条件すなおち加速度 $0.75 \mathrm{G}$ ，周波数 $5 \sim 50 \mathrm{~Hz}$ ，掃引 時間 5 分, 振動時間20分で, トマト果実は激しく振動 することが明らかになった。トマト果実の振動特性は 上下振動の加速度 $0.5 \mathrm{G}$ ではいずれの周波数でもトマ 卜果実が少し振動する程度であったが，1.0Gでは10 $\mathrm{Hz}$ 前後で激しく回転し踊りだした。水平振動では上 下振動に比べて，より低周波数で果実は激しく振動す ることが明らかになっだ)。

物理的損傷を防ぐために，緩衝材の効果を検討した。 輸送中に生じる完熟トマトの底部の損傷は上下ならび

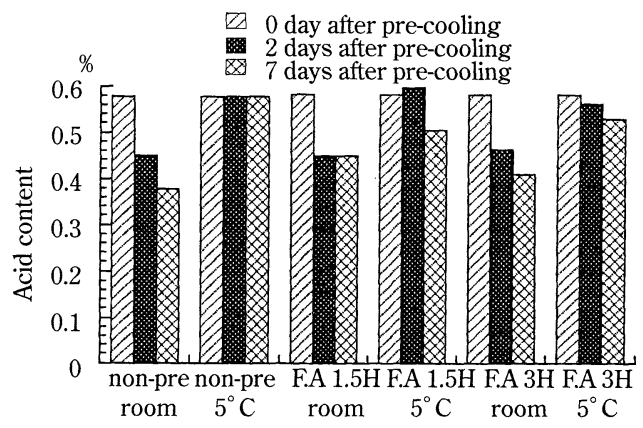

Fig. 1 Effects of pre-cooling and state of preservation on acid content of full-riped tomato

non-pre : non pre-cooling, F. A $1.5 \mathrm{H}$ : forced-air pre-cooling for 1. 5 hours, F. A $3 \mathrm{H}$ : forced-air pre-cooling for 3 hours

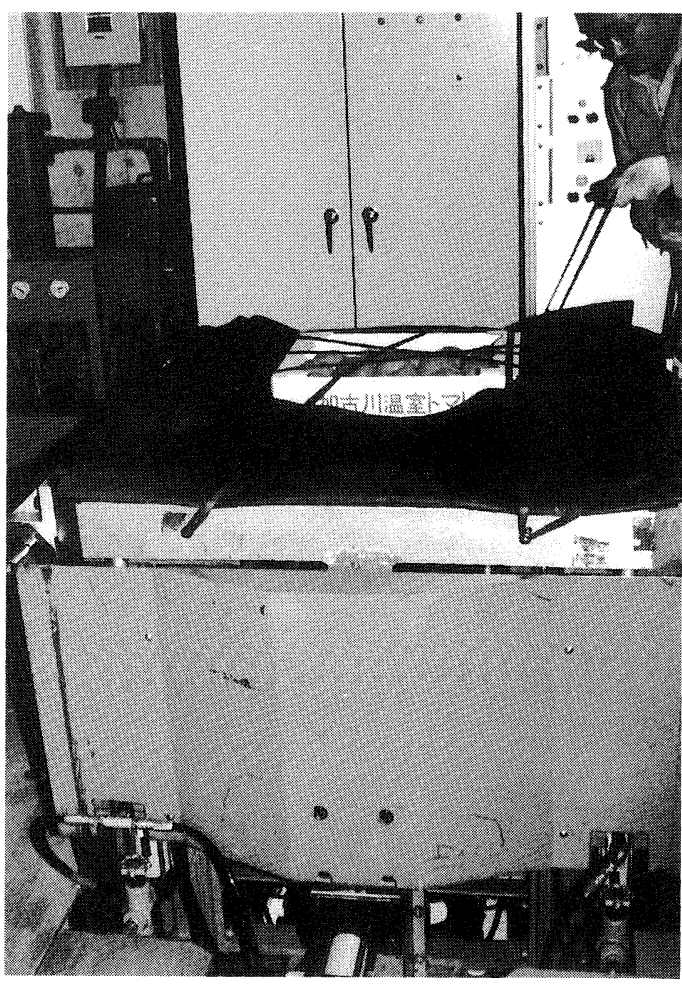

Fig. 2 The state of vibration test

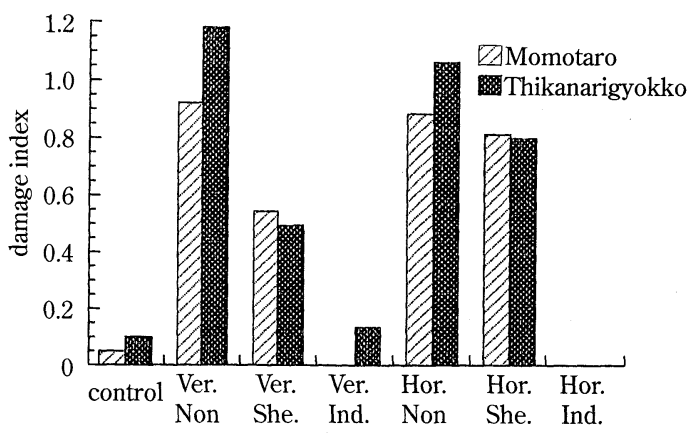

Fig. 3 Effects of shaking on physical damage of horizontal section of tomato through transporting simulation

The condition of test : acceleration degree $\cdots 0.75 \mathrm{G}$, frequencies $\cdots$ from 5 to $50 \mathrm{~Hz}$, rotation time $\cdots 5$ minites, shaking time $\cdots$ 20 minutes

Ver. : Vertical shaking, Hor. : Horizontal shaking She. : Sheet of styrene, Ind. : packed individually Non: Cardboard box only 
に水平振動ともに箱底に発泡スチロール製のシートを 使用することによりかなり抑制された。しかしながら， 側部の損傷は両振動方向ともに, 箱底のシートのみで はかなり発生しており，有効な対策は果実が直接接触 しない個別包装であることが明らかになった（Fig. 3)。 後に流通現場では紙製のトレーが使用されるようにな り, 果実同士が接触しない流通形態が確立された。

完熟トマトが誕生した時点の美味しいトマトの基準 は糖度 5.0 以上, 酸含量 $0.4 \%$ 以上であった。これは当 時の産地や農家の品質目標值でもあった。しかしなが ら, 今日市場流通している $8 \sim 9$ 割の完熟トマトがこ の目標值をすでに達成している。また, 当時の基準は 通年のものであり, 季節や作型により嗜好が異なるこ とも考えられる。そこで, 冬春収穫と夏秋収穫の二つ の作型について完熟トマトの味に関与する内容成分の 項目選定を行うとともに，消費者ニーズに対応した新 たな美味しさの基準值の検討を行った。糖度 5.2 , 滴 定酸 $0.45 \%$ の冬春トマトでは「うまい」との回答は 4 割程度で, 糖度 5 程度では満足されていないことが明 らかになった。夏秋トマトでは糖度が 8 以上のものは 「まずい」と答える人が増える傾向がみられた。完熟 トマトの食味と相関が高かった項目は冬春型では糖度 /滴定酸比, 夏秋型では糖度, 滴定酸含量であった。 このことからも，冬春型には甘さが，夏秋型には適度 の酸味が重要であることがわかる。「まずい」の回答 が10\%以下で,「うまい」の回答が $60 \%$ 以上を美味し さの基準と考え, 冬春トマトでは「糖度 6 以上, 滴定 酸 $0.5 \%$, 糖度/滴定酸比 12 程度」, 夏秋卜マトでは 「糖度 $6 \sim 8$, 滴定酸 $0.6 \sim 0.8 \%$, 糖度/滴定酸比 10 程度」との季節に応じた完熟トマトの美味しさの基準 值を策定した5),6)。

\section{2. 包装法の改善による夏季収穫ホウレンソウ の鮮度保持}

ホウレンソウの外観や成分変化には貯蔵温度が大き く影響する。低温ほど品質保持期間が長いことから， 一般に予冷・保冷等の低温流通が行われている。しか し, 実際の流通段階では品温の変化があり, 生産者か ら消費者にわたる間に品質低下を生じる場合があり， 大きな問題となっている。試験に取り組んだ産地のホ ウレンソウも, 夏季に量販店から売り場における鮮度 低下が指摘された。生産者および量販店等からは消費 者まで高鮮度の状態で流通できる軟弱野菜の高鮮度流 通技術の体系化がまさに望まれている。そこで，夏季 の高温期に収穫したホウレンソウの輸送中の品温変化
を測定するとともに，鮮度保持対策として出荷ケース とフィルム包装の改善による実用的な鮮度保持効果を 検討した。

収穫後のホウレンソウの品温変化を調查した結 果, 6 時間の予冷で品温は $26^{\circ} \mathrm{C}$ から $6 \sim 7{ }^{\circ} \mathrm{C}$ に低下し た。輸送中に品温は上昇し, 配送センター到着地点で

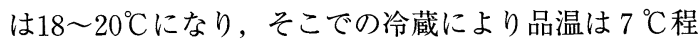
度に下がるものの, 店頭に出されるまでの間に配送等 で品温上昇がみられた。店頭では $18 \sim 20^{\circ} \mathrm{C}$ の品温に保 たれていた。このことから，流通の段階でかなりの品 温変化が生じていることが明らかになった。さらに， 品温変化は出荷ケースによっても異なっており, ダン ボール箱はプラスチック製組立通いケースに比べて品 温変化が遅く, 温度の変動幅が $3 \sim 4{ }^{\circ} \mathrm{C}$ 少なかった。 そのために，ホウレンソウの品質は組立通いケースに 比べてダンボール箱の方が優れていた。次に組み立て 通いケースで品質を保持する視点で補助包材の検討を 行った。組み立て通いケースの使用は「地球環境に優 しい流通」を目ざす量販店が導入したものであり，生 産者側も追随せざるを得ない状況にあった。補助包材 としての発泡スチロールシートの使用が最も流通途上 での品温変化が遅く, ホウレンソウの品質が優れてい た。現行の新聞紙 1 枚使用による保温に比べて, 新聞 紙を 2 枚使用することでも品温変化は小さくなり (Fig. 4)，品質低下が抑制できることが明らかになった7)。 ホウレンソウの呼吸量は貯蔵温度が高いほど多く, 収穫 7 日後では収穫直後の $60 \sim 70 \%$ に呼吸量が減少し た。呼吸量が多いほど，品質低下が早まることから， 収穫直後の品質保持対策が重要であることがわかる。 フィルム包装の検討では現行の開放状態から，上部

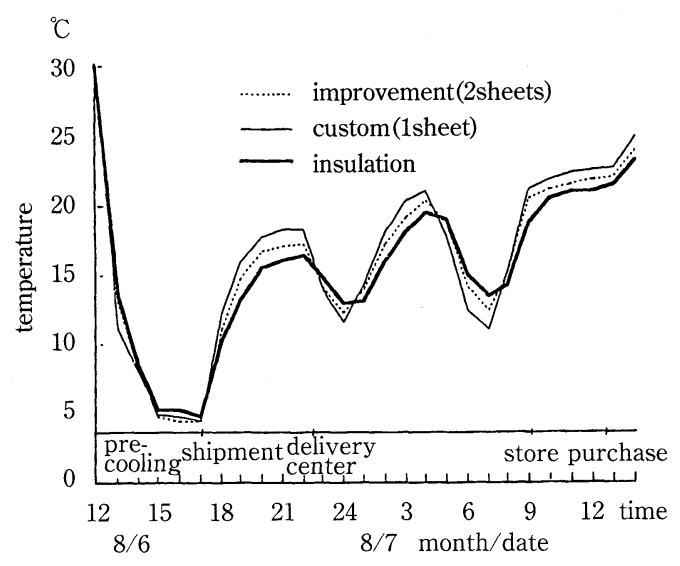

Fig. 4 Effect of supplementary packing on the changes of temperature in spinach during transportation 
Table 1 Effect of package method and change of storage temperature on quality in spinach 'Active'

\begin{tabular}{|c|c|c|c|c|c|c|c|c|}
\hline \multirow{3}{*}{ No. } & \multicolumn{2}{|c|}{ package } & \multirow{3}{*}{$\begin{array}{l}\text { keeping time } \\
\text { at room } \\
\text { temperature }\end{array}$} & \multicolumn{2}{|c|}{ fresh score ${ }^{* 5}$} & \multicolumn{2}{|c|}{ relative weight (\%) } & \multirow{3}{*}{ note } \\
\hline & \multirow{2}{*}{ film ${ }^{* 1}$} & \multirow{2}{*}{$\begin{array}{c}\text { sealig } \\
\text { method*2 }^{* 2}\end{array}$} & & \multicolumn{4}{|c|}{ storage period (days) } & \\
\hline & & & & 3 & 7 & 3 & 7 & \\
\hline (1) & $\mathrm{C}-\mathrm{OPP}$ & open & non & 4.2 & 2.5 & 97.8 & 95.1 & tip drying \\
\hline (2) & $\mathrm{C}-\mathrm{OPP}$ & open & $8 \mathrm{hr} . \quad$ ( 1 st day) ${ }^{* 4}$ & 2.5 & 2.0 & 94.1 & 89.1 & remarkable tip drying \\
\hline (3) & $\mathrm{C}-\mathrm{OPP}$ & open & $8 \mathrm{hr} . \quad(2 \mathrm{nd}$ day $)$ & 2.5 & 1.5 & 92.5 & 86.7 & remarkable tip drying \\
\hline (4) & $\mathrm{C}-\mathrm{OPP}$ & $S-W$ & non & 4.4 & 3.8 & 99.2 & 97.1 & \\
\hline (5) & $\mathrm{C}-\mathrm{OPP}$ & $S-W$ & $8 \mathrm{hr} . \quad$ ( 1 st day) & 3.5 & 2.8 & 98.7 & 97.4 & \\
\hline (6) & $\mathrm{C}-\mathrm{OPP}$ & $S-W$ & 8 hr. ( 2 nd day) & 3.5 & 3.2 & 98.6 & 97.8 & \\
\hline (7) & $\mathrm{C}-\mathrm{OPP}$ & sealed & non & 4.5 & 3.9 & 99.0 & 98.9 & \\
\hline (8) & $\mathrm{C}-\mathrm{OPP}$ & sealed & 8 hr. ( 1 st day) & 4.3 & 3.7 & 99.3 & 98.6 & \\
\hline (9) & $\mathrm{C}-\mathrm{OPP}$ & sealed & 8 hr. ( 2 nd day) & 4.0 & 2.5 & 99.0 & 98.6 & slight root rot \\
\hline (10) & $\mathrm{M}-\mathrm{OPP}$ & sealed & non & 4.5 & 4.0 & 99.1 & 98.9 & \\
\hline (11) & $\mathrm{M}-\mathrm{OPP}$ & sealed & 8 hr. (1 st day) & 4.4 & 3.6 & 99.7 & 98.9 & \\
\hline (12) & $\mathrm{M}-\mathrm{OPP}$ & sealed & $8 \mathrm{hr} . \quad(2$ nd day) & 4.3 & 3.6 & 99.1 & 98.9 & \\
\hline (13) & non & - & non & 1.8 & 1.0 & 83.7 & 61.2 & remarkable whole drying \\
\hline
\end{tabular}

* 1 film : C-OPP $\cdots$ custom polypropylene (no-hole-OPP) film (thickness : $25 \mu \mathrm{m}$ )

M-OPP $\cdots$ microhole-OPP film (thickness : $25 \mu \mathrm{m}$ ) treated with laser beams

* 2 sealing method: open $\cdots$ open at the upper part of pack, $\mathrm{S}-\mathrm{W} \cdots$ small windows type

* 3 spinach kept at room temperature for 8 hours after pre-cooling

* 4 date after harvest that spinach was kept at room temperature

* 5 fresh score : $5 \cdots$ Excellent $\sim 1 \cdots$ not edible

のみシールし底部に孔の開いた小空および密封形態に することで，高鮮度保持期間が延長できた（Table 1)。しかし，密封形態では蒸れを起こす可能性があ るので，小空形態が実用的なシール法であることが明 らかになった。ホウレンソウの集出荷現場では, 包装 機が全面シールから部分シールができるよう改良され， その後は品質のよいホウレンソウを生産, 出荷してい る産地として量販店等から高い評価を得ている。

\section{3.ブドウ「ピオーネ」の輸送中の振動特性と 脱粒防止法}

食生活の高級嗜好の中で, ブドウは大粒系が好まれ る傾向にあり，無核のピオーネブドウ（以下ピオー ネ）の需要は伸びている。しかしながら, 現在普及し ているジベレリン処理による無核化栽培では集出荷, 輸送中の振動で脱粒が生じやすく, 商品性が著しく低 下し大きな問題となっている。そこで，「ピオーネ」 の房の振動特性を明らかにするとともに脱粒防止対策 について検討した。

$1,000 \mathrm{~km}$ のトラック輸送試験に使われるJIS規格の振 動条件で, ピオーネの果粒は激しく振動することが確 認された。水平振動での加速度特性 $(7 \mathrm{~Hz})$ は $0.5 \mathrm{G}$ で果粒が振動し，0.8Gで房が激振し，1.0Gで房が激
しく擦れ合い，1.2Gで脱粒が発生した（Fig. 5)。

振動による脱粒は収穫時期が遅れるほど多く発生し た。収穫の 1 カ月前にKT-30（サイトカイニン類）液 剂噴霧処理を行うことにより, JIS規格の振動条件下 では振動直後の脱粒は生じなくなり, 振動 2 日後にお いても脱粒数が $1 / 2$ 以下に減少した（Table 2$) 。 そ$ の要因はKT-30液剤噴霧処理で果粒の引つ張り強度が 高まることであった。しかも，KT-30剤の濃度が高ま るほど引っ張り強度が高まり, 果粒そのものが一層離 脱しにくくなっていることが明らかになった。しかし ながら，ピオーネの品質面において色調はKT-30剤の 濃度が高いほどL值, a值が高く, 着色の遅れがみら れることと, 糖度, 糖度／滴定酸比が低下する傾向が みられるので，実用的な処理技術としては $5 \mathrm{ppm}$ 程度 が適濃度であると考えられる。また, 発泡スチロール 製ネットの緩衝材を用いることで, JIS規格の振動条 件による振動直後および振動 2 日後の脱粒数は緩衝剂 がない区に比べて $1 / 2$ 以下に減少した。さらに, KT -30処理と緩衝材の複合技術で脱粒がさらに抑制でき ることが明らかになった ${ }^{8,9)}$ 。 KT-30液剂処理の効果 として収穫が遅れても脱粒しにくくなることからピオ 一ネの収穫期間の拡大技術としても利用できるものと 考えられる。 
Influences of frequencies at an acceleration degree of $1.0 \mathrm{G}$

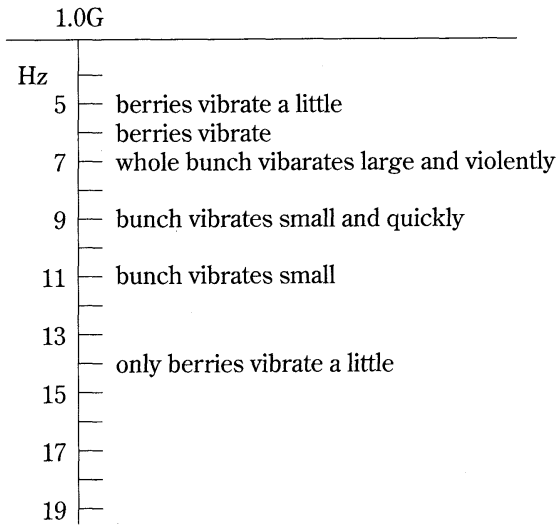

Influences of acceleration degrees at a freqrency of 7 hertz.

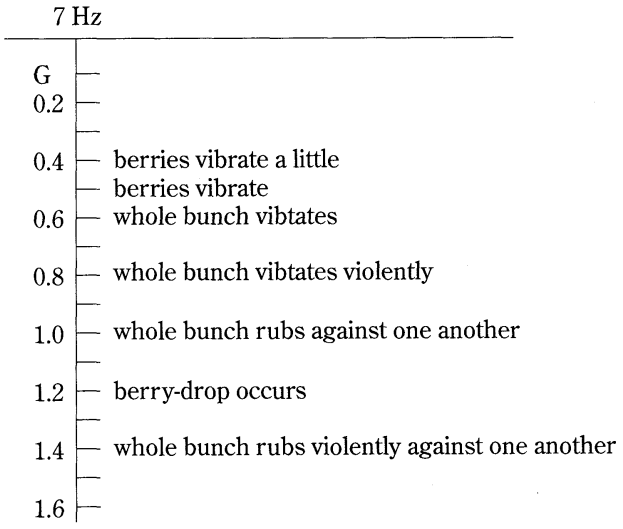

Fig. 5 State of vibration of grapes 'Pione' which are influenced by acceleration degrees and frequencies through transporting simulation (horizontal shaking)

Table 2 Berry-drop of grapes 'Pione' which were treated with KT-30 through transporting simulation

\begin{tabular}{ccllccc} 
date of & $\begin{array}{c}\text { KT-30 } \\
\text { treatment }\end{array}$ & \multicolumn{1}{c}{$\begin{array}{c}\text { stage of } \\
\text { maturity }\end{array}$} & $\begin{array}{c}\text { shock } \\
\text { absorber }\end{array}$ & $\begin{array}{c}\text { shaking } \\
\text { test }\end{array}$ & $\begin{array}{c}\text { berry-drop just } \\
\text { after shaking } \\
\text { (per bunch) }\end{array}$ & $\begin{array}{c}\text { berry-drop after } \\
\text { 2 days of shaking } \\
\text { (per bunch) }\end{array}$ \\
\hline Aug. 24 & non & immature & non & done & $0.0^{*}$ & 0.5 \\
Aug. 24 & non & immature & treated & done & 0.0 & 0.2 \\
Sep. 3 & non & table ripe & non & done & 0.5 & 1.8 \\
Sep. 3 & non & table ripe & treated & done & 0.2 & 0.5 \\
Sep. 3 & $5 \mathrm{ppm}$ & immature ripe & non & done & 0.0 & 0.8 \\
Sep. 3 & $5 \mathrm{ppm}$ & immature ripe & treated & done & 0.0 & 0.5 \\
Sep. 3 & $20 \mathrm{ppm}$ & immature ripe & non & done & 0.0 & 0.2 \\
Sep. 3 & $20 \mathrm{ppm}$ & immature ripe & treated & done & 0.0 & 2.6 \\
Sep. 16 & non & overripe & non & done & 1.6 & 0.8 \\
Sep. 16 & non & overripe & treated & done & 0.6 & 1.2 \\
Sep. 16 & $5 \mathrm{ppm}$ & table ripe & non & done & 0.0 & 0.5 \\
Sep. 16 & $5 \mathrm{ppm}$ & table ripe & treated & done & 0.0 & 0.3 \\
Sep. 16 & $20 \mathrm{ppm}$ & immature ripe & non & done & 0.0 & 0.2 \\
Sep. 16 & $20 \mathrm{ppm}$ & immature ripe & treated & done & 0.0 & 0.0 \\
Sep. 3 & non & table ripe & non & non & 0.0 & 0.0 \\
Sep. 16 & non & table ripe & non & non & 0.0 & \\
\hline
\end{tabular}

* : The number of berry-drop per bunch

KT-30 treatment: KT-30 solutions were sprayed over upon whole bunches on Jul. 24

The shaking test by transporting simulation was done soon after harvest.

The condition of test : acceleration degree $\cdots 0.75 \mathrm{G}$, frequencies $\cdots$ from 5 to $50 \mathrm{~Hz}$ rotation time $\cdots 5$ minuites, shaking time $\cdots 20$ minutes

\section{4. クリにおける収穫後の品質向上技術の確立}

クリの収穫期は 9 月上旬から 10 月下旬の短期間に集 中する。特に 9 月下旬から 10 月上旬の市場出荷量は最 大となり，この時期の市場価格の低下が著しい。また， 近年は韓国, 中国からの剥きグリ輸入が増加し, それ に伴いクリの国内生産量は過去10年間徐々に低下して
いる。このような状況の下で，今後とも国内産グリの 消費の維持拡大を図るには栽培面での高品質化はもと より，収穫後の果実についても貯蔵による食味向上策 を図り, 出荷調整をする必要性が一層高まっている。 そこで, 食味の優れた国内産大粒グリの出荷, 流通技 術を確立するために, 大粒日本グリの貯蔵温度, 貯蔵 期間とクリの糖含量との関係を調査した。また, 消費 
ニーズに対応しクリの甘さ調節の可能性について検討 した。さらに，糖含量を高めた大甘栗が周年供給でき る調理グリの製造法について検討した。

クリ果実は低温条件 $\left(-2 \sim 5{ }^{\circ} \mathrm{C}\right)$ でデンプンが減 少し, ショ糖, 全糖含量が増加した。貯蔵条件 $0{ }^{\circ} \mathrm{C}$ 、 2 週間で全糖含量が収穫時の $1.7 \sim 3.1$ 倍となった。 0 ${ }^{\circ} \mathrm{C}$ での全糖含量の増加速度は, 品種によって異なるが, 全糖含量はほぼ $4 \sim 6$ 週間でピークに達し, その後緩 やかに減少した（Fig. 6)。その速度は最初は速く，そ の後は徐々に減少した。また，晚生品種ほど早く糖含 量がピークに達する傾向がみられた。糖含量の増加に 比例して, 色調のb值（黄色度）が高まる傾向にあっ た。主たる甘み成分であるショ糖は 3 日程度の短期間 の低温処理でも増加が認められた。低温処理により甘 みの増したクリをその後常温で約 2 週間貯蔵してもシ ヨ糖含量の增減がほとんど生じなかった（Fig. 7)。こ のことから，甘さの異なるクリを作成し，常温で流通 することが可能であることが明らかになっだ10。

糖含量の高まったクリを冷凍貯蔵し，食べる直前に 凍結の状態で加圧湿熱調理すれば，凍結前に蒸したの と同程度に風味，舌触りがよい美味しい蒸しグリを周

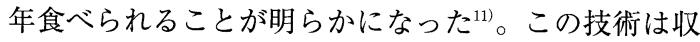
穫直後に低温処理し，その後凍結するので，従来の燻 蒸処理が不要となり安全性の点でも優れている。

甘さの異なるクリを作成し，450人の甘さに対する 嗜好を調查した結果，ショ糖含量を高めたクリの方が 美味しいと答えた人は全体の $84 \%$ と多く，甘いクリが 好まれていた。クリの食味はショ糖含量との相関が特 に高いことから，甘さの程度についてショ糖含量が $4.5 \%$ 末満を普通，4.5〜8\%を甘，8\%以上を極甘と する基準を策定した ${ }^{12)}$ 。今後流通するクリに甘さの程 度の表示がなされるようになれば，消費者は好みの甘 さのクリを選択できるようになり，消費拡大と地域ブ ランド化に役立てることができる。

現在,「丹波ささやま」で名高い兵庫県篠山市にあ る「ささやま特産館」では 1 年中いつでも甘くて美味 しい焼きグリ風蒸しグリ（Fig. 8）を食べることが可 能となった。また，大粒甘栗を食材としたお菓子など 新しい商品開発も検討されている。

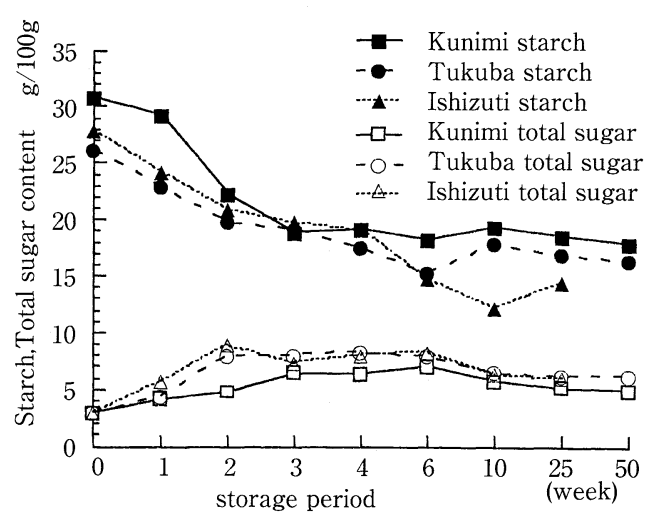

Fig. 6 Effects of $0{ }^{\circ} \mathrm{C}$ storage on starch and toral sugar content of chestnut

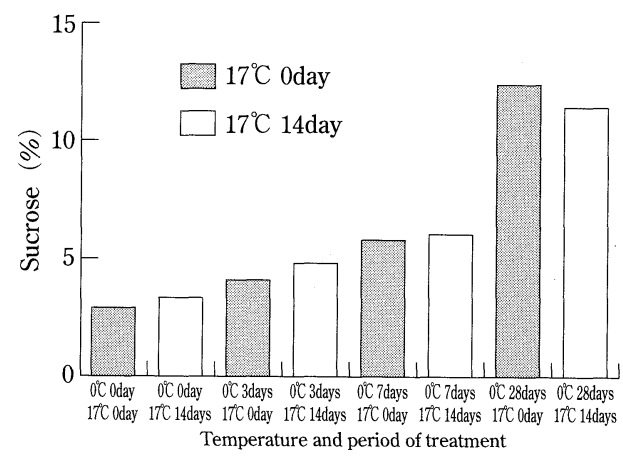

Fig. 7 Changes of the sucrose content in chest nuts by short storage at $0{ }^{\circ} \mathrm{C}$

1) Means treatment of 3 days with $0{ }^{\circ} \mathrm{C}$ and 14 days with 17 ${ }^{\circ} \mathrm{C}$ later

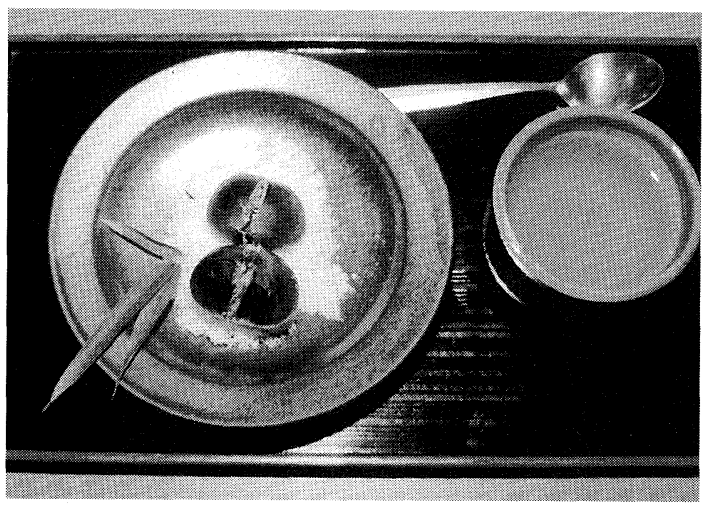

Fig. 8 Sweet chestnut of Sasayama - tokusankan 


\section{おわりに}

流通利用部門の仕事に13年間携わったが，その間に 上記以外の品目としてミニトマト ${ }^{13), 14)}$, タマネギ15), ヤマノイモ ${ }^{16)}$ の品質, 貯蔵技術, キャベツ ${ }^{17)}$, ブロッ コリ ${ }^{18)}$, レタス ${ }^{19)}$ の品質保持, 温州ミカン ${ }^{20)}$, ユズ ${ }^{21)}$ の品質，品質保持等の研究にかかわってきた。それら を通じて感じたことは, 生産者にとって, つくる技術 はもちろん重要であるが, 売る技術の必要性が一層増 してきていることで, 農産物の品質評価がより重要に なることである。栽培部門と流通利用部門の研究者が 一環して研究に取り組める環境下で, しかも現場の普 及員や営農指導員, 栽培農家の協力が得られて, はじ めて現場に役立つ技術が確立できると思った。また， 鮮度や品質の測定方法は確立されておらず，他の部門 に比べて調査や分析方法に創意, 工夫が求められ, そ れらが活かされる研究分野だと感じた。筆者は約 1 年 前流通利用部門から土壤肥料部門に仕事が変わった。 土壤肥料部門はこれまでとはかなり異なった分野であ る。この新しい分野の仕事にかかわりをもち，この分 野にも多くの課題が存在することがわかりつつある。 これまで取り組んできた流通利用部門の知識や経験を 土壤肥料部門の新たな課題解決のために少しでも多く 活かしたいと考えているこの頃である。

謝辞本研究を行うにあたり，ご指導とご助言 をいただいた元神戸大学教授土田廣信博士に心から御 礼申し上げます。また，兵庫県立北部農業技術センタ 一加工流通部の澤正樹前部長, 同部の中川勝也部長, 井上喜正次長をはじめ多くの方々のご助言, ご協力を いただいたことに深く感謝を申し上げます。

\section{文献}

1）永井耕介・吉川年彦 - 澤 正樹 : 兵庫中央農技研 報 (農業編)，39，101～106（1991）

2 ) 永井耕介-有方千裕 - 小河拓也 - 中川勝也：近畿 中国農研，89，45～50（1995）

3 ）永井耕介・吉川年彦・澤 正樹 - 岸本基男 : 近畿 中国農研，82，34～38（1991）

4 ）永井耕介・吉川年彦 - 澤 正樹：近畿中国農 研, 80, 54〜58（1990）
5 ）永井耕介・吉川年彦 - 澤 正樹 - 小林尚司 - 田中 平義：日食低保誌，15（2），75～81（1989）

6 ）永井耕介-中川勝也：近畿中国農研, $90,30 \sim 33$ (1995)

7 ）永井耕介・羽渕維子 - 小河拓也 - 中川勝也：日食 低保誌，23（3），133～138（1997）

8 ) Nagai, K., Hamada, K., Ogawa, T. and NAKagawa, K.: J. Japan. Soc. Cold Preserva. Food, 22 (4), 223 229 (1996)

9 ）永井耕介 - 浜田憲一 - 小河拓也 - 中川勝也：近畿 中国農研，89，41～44（1995）

10）永井耕介・堀本宗清 - 澤 正樹 - 吉川年彦：兵庫 中央農技研報（農業編），40，29～34（1992）

11）永井耕介：農業機械学会誌, 57 （3），131～135 (1995)

12）永井耕介 - 堀本宗清 - 小河拓也 - 中川勝也：日食 低保誌, 22（2），91～95（1996）

13）永井耕介 - 吉川年彦 - 中川勝也 - 澤 正樹 - 田中 平義：兵庫中央農技研報 (農業編)，36，103～106 (1988)

14）永井耕介・吉川年彦 - 中川勝也 - 澤 正樹 - 田中 平義：兵庫中央農技研報 (農業編)，37, 29 34 (1989)

15）永井耕介・澤 正樹 - 吉川年彦 - 岸本基男 - 山田 正敏・中川裕八郎・伊佐定夫：日食低保誌, 18 (4)，141〜147（1992）

16）永井耕介- 田畑広之進 - 有福一郎 - 小河拓也 - 廣 田智子 - 福嶋昭 ·井上喜正：日食低保誌, 25（4), 169 173 (1999)

17) Nagai, K., Fukushima, A., Ogawa, T., Matuura, K. and NAKAgAWA, K.: J. Japan. Soc. Cold Preserva. Food, 24 ( 1 ), 11 16 (1998)

18）永井耕介 - 小河拓也 - 福嶋 昭 - 中川勝也：日食 低保誌，23（6），323～328（1997）

19）永井耕介- 小河拓也 -中川勝也：兵庫中央農技研 報 (農業編)，46，45～50（1998）

20）永井耕介：近畿中国地域における新技術（近畿中 国農業試験研究推進会議編)，28，204～206（1994） 21）永井耕介 - 田畑広之進 - 小河拓也 - 岸根秀明 - 井 上喜正：近畿中国農研，101，57～61（2001） 